\title{
Glocalising Cultural Desire: Texts on the Overseas Filipina Worker (OFW)
}

\author{
LILY ROSE TOPE \\ Department of English and Comparative Literature, \\ College of Arts and Letters, University of the Philippines \\ Diliman, Quezon City 1101, Philippines \\ lrtope@yahoo.com
}

Published online: 30 December 2016

To cite this article: Lily Rose Tope. 2016. Glocalising cultural desire: Texts on the overseas Filipina worker (OFW). KEMANUSIAAN the Asian Journal of Humanities 23(Supp. 2): 119-136, https://doi.org/10.21315/kajh2016.23.s2.7

To link to this article: https://doi.org/10.21315/kajh2016.23.s2.7

\begin{abstract}
The export of labour in the Philippines has been a state response to a failing economy. Filipino labour, one of the biggest assets of the Philippine state, became in great demand in the United States, Middle East, Europe and the rich countries of Asia. In the last decades, the demand for female labour has equalled and sometimes surpassed that for male labour. Female foreign workers from the Philippines laboured mostly as maids, caregivers, medical personnel and entertainers. My study posits the idea that the social conditioning of the Filipina in the home and the community prepares her to be a good Filipino woman and that these same traits make her an attractive commodity in the global market. Local and global expectations split the Filipina worker's subjectivity. For instance, trained to be an agent of nurture within the family, she is preferred by employers in nursing and caregiving facilities overseas. Trained in the musical culture of the Filipino household and community, she is preferred as an entertainer in hotels and bars. The study furthermore examines the tension between the cultivation of a local cultural good and its transformation into an instrument of commercial profit and exploitation when it enters the globalised space. The globalised subjectivity returns to the local with mixed results. This paper will use literary texts on the overseas Filipina worker as they explore her evolving subjectivity during the process of glocalisation.
\end{abstract}

Keywords and phrases: globalisation, foreign labour, Overseas Filipina workers, glocal, subjectivity 


\section{Introduction}

The export of labour in the Philippines has been a state response to a failing economy. Filipino labour, one of the biggest assets of the Philippine state became a currency to local efforts to save the economy and a globalised way of addressing local needs and desires. Like all kinds of migration, labour migration is subjected to the push pull factors that determine its extent and nature. The push factors come from the donor or country of origin, its state and condition often contributing to the exit of brawn and talent. The pull factors emanate from the host country, its appeal usually due to the presence of opportunities that are lacking in the donor countries.

In the case of the Philippines, poverty is the biggest push factor, followed by lack of opportunities in social mobility and by lack of a general sense of well-being due to civil shortcomings such as the low level of peace and order, corruption, and a pervading sense of impunity against injustice and abuse of power. All these have existed a long time in the Philippines due to historical exigencies. Philippine labour migration in great numbers seem to have begun in the early 20th century with the passage of hundreds of fruit pickers and fish canners who went to America in search of a better life.

But these are not the migrants who are subject of this study. There is a second category of Filipino labour migrants whose aims and conditions are different from those who went to America. The second big wave of migration began in the 1970s when worsening socio-economic problems were becoming untenable and government could not redress poverty and unemployment effectively. Reeling from the overwhelming issues of social unrest and balance of payment problems, the government found a serendipitous solution in export of labour. It officially adopted the overseas employment policy which provided privileges and protection for the contract worker which in turn made contract work appealing.

\section{The Overseas Filipino Worker (OFW)}

Who is the labour migrant? This one, unlike the first kind, does not intend to stay in the host country and is just there to work. She is bound by a contract to an employer, thus the term overseas contract worker. According to the latest figures from the Philippine Statistics Authority, the total number of overseas Filipino workers who worked abroad at anytime during the period of April to September of 2015 was estimated at 2.4 million. Of these, $97.1 \%$ have existing contracts while the rest are undocumented, thus the more inclusive term OFW. Initially, men slightly outnumbered the women. The largest number of OFWs were in the age groups 25-29 years old and 30-34 years old. Saudi Arabia continues to be the leading destination but other popular destinations are the United Arab 
Emirates, Qatar, Singapore and Hong Kong (Philippine Statistics Authority 2015). OFWs can also be found in big numbers in the United Kingdom, Italy, Malaysia, Israel, Taiwan, South Korea and Japan.

The OFW's profile says that only $10 \%$ are educated. This $10 \%$ serve as managers and executives in the Middle East and Southeast Asian countries (National Statistics Office 2012). A big number are employed in medical facilities all over the world. But the greater majority are low skilled and do menial jobs locals shun. They work as (Patterns of Migration 1995, 2)

Domestic helpers and caregivers to the young and old of Hong Kong, Singapore, Australia, Italy, UK, Israel; as dancers and singers in Japan and Southeast Asia; as chamber maids and waiters in Dubai, Germany; as laborers in the oil refineries and construction firms of Saudi Arabia, Kuwait; as factory workers in Taiwan, South Korea, as seafarers in foreign waters.

The life of a low skilled OFW entails physical labour and compared to their more educated compatriots, who were hired for their high level skills, low skilled workers have to endure less comfortable working conditions. They are usually in "3D jobs", jobs that are "dirty, dangerous and difficult" (Tolentino 2011, 230). But this is more or less expected and the OFWs brace themselves for this. Perhaps even more difficult are the social and emotional challenges of working overseas. They have to endure loneliness and homesickness, the distance from their families causing great anxiety and sometimes even regret. They also have to endure the demeaning of their culture by employers who do not understand their ways. The burden of departure and distance would take its toll on the well-being of these workers. Those psychologically unprepared find themselves in disadvantageous situations usually involving infidelity, unprofessionalism, overspending, etc. which also gave OFWs a bad name. Some receiving countries such as Hong Kong and Singapore provide support for the OFWs by encouraging the creation of centers that will give them additional skills, social and psychological guidance and opportunities for social interaction with fellow Filipinos.

\section{Gender Shift in Filipino Overseas Labour}

In the 1980s, a new shift in labour demand was detected. There was an increase in the demand for female overseas workers which could be traced to the shift of the labour economy from manufacturing to service, the increasing participation of women in the work force of the importing countries and the emergence of a new middle class with an improved lifestyle and new found leisure. Filipino 
educated women began working as baby sitters and domestic helpers. "Of the total landbased workers deployed in 1993, 55\% were composed of women. In the 90 s, $95 \%$ of OFWs in Japan were women. Filipina migrant workers make up $85 \%$ of over 400,000 of the estimated half a million Filipinos in Europe" (Feminization of Migrant Labor 1995, 8).

The term "Filipina" has become "synonymous with maid, caregiver, and performer of domestic work in affluent noveau riche families in the global economy. Filipina denotes 'maid' in Hong Kong and 'nanny' in Canada as well as in Taiwan and Italy. In Greece, the new entry in a local dictionary set 'Filipineza' (Filipina) as a domestic servant, someone who performs non-auxiliary tasks" (Tolentino 2009, 422). This has given rise to what one Filipino feminist newspaper columnist calls the "vaginal economy" (Jimenez-David cited in Tolentino 2009, 229). "Once referring to Filipinas who were trafficked or involved in sex work, vaginal economy now refers to the female sex as the primary instrument of national development and is characterised by massive deployment of contract workers, the greater sexualisation of female labour (i.e. being breadwinning yet absent mother, transnational mothering and care, transnational economy of emotions and devotion, or being a woman, foreign and doing socially reproductive work). They do 3D work, not just dirty, dangerous and difficult, but also domestic, degrading and demeaning" (Tolentino 2011, 230).

Admittedly, as maids, Filipinas are at the top of the bracket. Her knowledge of English and sometimes her college education serve her well. But her qualifications do not protect her from her vulnerabilities (Tolentino 2009, 425).

While nation states can protect themselves from an economic crisis, foreign domestic workers are vulnerable to it. During the height of the 1997 economic crisis, Hong Kong employers pushed a 5\% wage cut in the salary of domestic workers. At the beck and call of household owners, the Filipina and her work are highly regimented, in most cases, detailed to what she can and cannot do in terms of monitored work and sleeping schedule. According to the Asian Migrant Centre, more than $75 \%$ of all domestic workers studied in Hong Kong worked for more than 14 hours a day, almost a third worked 16-17 hours a day. The Filipina domestic worker like other migrant workers has yet to be protected by the UN Convention on the Protection of the Rights of all Migrant Workers and Members of their Families as only 12 countries, mostly those that export labour, have ratified the convention. 
Despite these, the OFW who lands on foreign soil is grateful. Why does Filipino female labour migration continue to increase? What promotes her role and qualifications as a migrant labourer? Where is she located in terms of local and global expectations? My study posits that the social conditioning of the Filipina in the home and the community prepares her to be a good Filipino woman and that these same traits make her an attractive commodity in the global market. Local and global expectations split the Filipina worker's subjectivity. For instance, trained to be an agent of nurture within the family, she is preferred by employers in nursing and caregiving facilities overseas. Trained in the musical culture of the Filipino household and community, she is preferred as an entertainer in hotels and bars. The study furthermore examines the tension between the cultivation of a local cultural good and its transformation into an instrument of commercial profit and exploitation when it enters the globalised space. The globalised subjectivity returns to the local with mixed results.

This study will use literary texts and a film on the overseas Filipina worker written by Filipino and Singapore authors and filmed by a Singaporean director as they explore her evolving subjectivity during the process of glocalisation. I will focus on two kinds of Filipina labour migrants, namely, the domestic helper and the entertainer, both of whom are in the lowest rung of the female labour spectrum.

\section{The Push Factor: Family}

To provide a contextual explanation of the OFW discourse, this study refers to her early conditioning. A Filipino child during primary grades would be taught to love God, country and family in that order. But since God and country are often abstract, family will be the logos of her material life. Youngblood $(1973,761)$ observes that family is a central trope to Filipino values and behaviour.

That the family is the training ground for roles which will be played later in society has been emphasized throughout the literature on socialization. It is in this context that the individual learns the fundamental patterns of his culture's social behavior and acquires his first experiences with authority and discipline. The family is also the institution in which the individual begins to develop a sense of self as he receives and interprets cues from his mother, father and siblings.

Kinship solidarity is inculcated at an early age so as a Filipino matures, his behavior is increasingly determined by considerations for the welfare, name, and status of his family and 
relatives with the understanding that his successes and failures as well as theirs, reflect on the entire group. Moreover, he is taught from early childhood that beyond the boundaries of the family the world is full of risks and dangers that cannot be anticipated. The result of this kind of a socialization process is that a Filipino will seldom risk being cut off from the social group into which he is born, for engendering displeasure of one's family is not only dangerous but implies bad character as well.

The family is the source of the Filipina's local desires. It binds her to a sense of duty and affection and in return is provided with affirmation and sense of purpose. Even in cases of abuse, a wife or a daughter will not easily sever ties with the abuser, often hoping that a sense of family will eventually win over dysfunctional conditions or selfish concerns, that change and forgiveness can be expected at the end. Such narratives are solidified by popular cultural texts and the media.

Rarely does a Filipina migrant labourer leave her family for reasons of individual improvement alone. More often than not, she leaves to support her family- to send the children to school, to buy the husband a jeepney so he can earn a living, to replace the house roof which was damaged by the recent typhoon, to buy her parents medicine and restore them to good health. Later maybe she can even build a nice house and be the envy of her relatives and neighbours or set up a business after the children have finished their college degrees. Meantime, she has to set personal happiness aside.

The female characters in several texts represent these desires. Nina in Philip Jeyaretnam's story "Traps" taken from his collection First Loves is an example. Nina is depicted as a college graduate forced to enter foreign domestic labour because of dispossession. Her family was displaced by a big multinational company in rural Mindanao and lost the land they were tilling. Her father worked himself to death to send her to school, and when he died, she assuages her guilt by supporting her family. Finding her literature degree non-marketable, she finds domestic labour in Singapore as her only option. The story builds the perception that the Filipina maid is not ignorant, she is simply trapped by poverty and filial duty (Tope 2015, 124). Then there are the three mothers in Suchen Christine Lim's short story Gloria, Carla Pacis' (1999) novel for young adults, O.C.W. A Young Boy's Search for His Mother and Anthony Chen's film Iloilo. All three brave the uncertainty, the expected servitude and silencing of selves in foreign domestic service. Gloria begins to dream of bringing her son to Singapore to show him the wealth of goods in a Singapore supermarket unheard of and unseen in their village. The mother in O.C.W. A Young Boy's Search for His Mother is a 
public school teacher lured to Hong Kong by her desire of a better future for her children. Teresa or Terry in the film Iloilo suppresses homesickness and culture shock to be able to continue working. The Filipina worker's love for her family is the impetus that provides the drive, the courage, the willingness "to forego personal ambitions" (Youngblood 1973, 762). Ironically, nothing is worth leaving the family except the betterment of the family.

There are many cases of fulfilled desires. Those who persevere are rewarded with an improved quality of life. Moshe Semyonov and Anastacia Gorodzeicky, in their study of OFW households, say that there is general improvement in the life of OFW households. They eat better, their children are in better schools. When the OFWs return home, each homecoming is a triumph of sorts, a proof of success and survival. If only for this, they are heroes to their families.

But they are heroes to their nation too. The total remittance by OFWs in 2015 was estimated at USD 180.3 billion pesos or USD 3.91 billion (Philippine Statistics Authority 2015). OFW remittances have time and again saved the economy of the cash strapped country. Consequently, several presidents have honored them by calling them Bagong Bayani or new heroes.

The Philippine government is required to help OFWs who are in trouble-rescue them when caught in a war, negotiate with receiving governments for judicial pardons or compassion for illegal workers, release them from abusive employers, etc. This is the least a grateful government and people can do. And yet there are times when they are still denied help. In the Philippines, everyone has a relative or acquaintance who is an OFW. It is an inescapable and historically irrevocable phenomenon that has marked the Filipinos as a people. Both the blessing and pain are etched in our cultural history (Tope 2015, 439).

\section{Emotional Capital and Labour}

Fifty percent of low skilled Filipina OFWs go to the service and entertainment sector. What makes the Filipina a sought after domestic caregiver or entertainer? From young, a Filipina is conditioned in her social roles to be a good daughter and mother. From her own mother, she learns how to look after her familydoing domestic chores, performing caregiving functions to her husband, children, parents, parents-in-law and various relatives. She must be sensitive to the needs of her family, comforting and consoling in moments of adversity, encouraging and enabling when there are obstacles to overcome; she is loving to her husband, ideally a willing sexual partner as well; she is confidante to her children, included in their moments of triumph and fun. She must be dutiful to her ageing parents and parents-in-law, a comfort in their last years. Manila has a population of 
10-12 million but one can count with one's fingers the number of facilities for the elderly. Filipinos still do not have the culture of sending their elderly to facilities. It is still unthinkable not to take care of them at home. All these she must not regard as a burden but as an expression of loyalty and love.

The point here is the wealth of emotional capital created by a traditional conditioning which the Filipina worker brings to her work. She does not just provide physical labour but emotional labour as well. When she becomes a domestic worker, she is "bound to the script of 'maternalism and deference"'. She is "expected to nurture the emotional being of people" she works for (Parrenas 2001, 364). The Filipina OFW uses her emotional capital for emotional labour, creating what I call the process of surrogacy. As a maid, she becomes surrogate mother. Almost all the reproductive functions are passed on to her, with the mistress of the house allowed the freedom to function reproductively at her own discretion. Because maids allow wives to join the labour force and have a professional life, the female employer also receives emotional service from the maid as with the rest of the employer's family.

In the story Gloria, the children are left to the care of the maid, Gloria. Here the busy Singaporean mother abandons her reproductive functions, supervising only through the telephone. When the children establish intimacy with the maid, she feels threatened ( $\operatorname{Lim} 2007,1-2)$.

So she sits on the cane chair in the balcony, and the boy, Timmy, the youngest of the two boys and a girl under her charge, has come out to sit with her. She wraps her arms around his warm tubby belly, inhaling the lavender fragrance of the talcum powder she has rubbed on him after his bath. When she has saved enough, she will buy a small tin of the same Johnson \& Johnson talc powder to take home to Migoy and Amy, her two youngest. She kisses the boy's head.

"Timmy! Come in here!"

With a start, her arms drop to her side. The boy runs to his mother.

"What're you doing in the balcony, darling? Full of mosquitoes out there.

Sit here with Mummy. Gloria!"

"Yes, Ma'am."

"Have you finished washing the dishes?"

"Yes, Ma'am." 
"What about the kitchen towels? Did you wash them and hang them up to dry?"

"Yes, Ma'am."

"Bring out the chocolate cake in the fridge. And don't forget the plates and forks this time."

"Yes, Ma'am."

She goes into the kitchen again, returns with the cake, the plates and forks on a tray.

She sets it on the coffee table.

"How am I to cut the cake without a knife? And you forgot the napkins."

"Yes, Ma'am."

She goes into the kitchen again, returns with the cake knife and some napkins.

"No, you don't cut it. I'll cut it. You still have laundry to do tonight, don't you?"

"Yes, Ma'am."

"Well, what are you waiting for then? I don't need you here."

She retreats into the kitchen, and sits on the floor of the narrow alcove where the laundry is hung and where she sleeps at night. She sits beside her suitcase, the green and brown canvas suitcase that Tita Flora had lent her when the village knew that she was coming to Singapore to work. She sits beside it, her brown brawny arms wrapped around her shoulders, rocking her upper body back and forth, back and forth, as though she was rocking her baby. Her little Migoy.

In the film Iloilo, the boy Jian Le is also entrusted by his mother to the care of Terry. The father loses his job and the pregnant mother is careful she does not lose hers. Sensing trouble at home, the boy misbehaves in school and gives Terry a hard time. But she soldiers on, standing outside his classroom door to catch him when classes end. She does not squeal on him when he gets into an accident. When the mother is called to come to school, she is too busy at work. Terry dons her best dress and goes in her stead. The mother finds out and scolds Terry. Later, Jian Le punches a classmate when the latter suggests that Terry loves him because she is paid to do it. Both Terry and Gloria do what comes naturally to them. Protective towards their wards, they channel conditioned emotions towards the children, playing surrogate mothers to "abandoned" children, instinctively knowing the children's emotional needs and fulfilling them without a second thought, erasing the boundary between work and care. In the Philippines, where it is not impossible to receive care from a stranger, the hardline distinction between 
family and service provider is often seen as class discrimination, and while practised among middle class families, is frowned upon among the lower classes. It is not unusual for maids to adopt their wards emotionally and thus the reaction of the two Singaporean mothers and Jian Le's classmate can be seen as a product, hopefully not of racial construction, but of the corporate culture of Singapore where relationships are often, but not always, transactional. A maid is a maid, not a mother. The fact that emotional labour has limits and boundaries suggests that emotions are commodified and the term emotional labour is thereby appropriate.

Surrogate motherhood by Filipino domestic helpers is an offshoot of suppressed maternalism created by another phenomenon called transnational families. Parrenas (2001) who has done a solid and significant study of Filipino female domestic labour migration has produced a comprehensive but complex discursive map of the Filipina OFW. Her study shows that the Filipina OFW carries a double emotional burden when she leaves her family. The first burden is her emotional service to her employers, as previously discussed, and the second burden is her continued mothering role to the children she left behind. Partly because very few Filipino fathers are willing to take the cudgels of mothering, her mothering functions do not pause with her absence. In fact, she adopts "transnational mothering" by continued caregiving long distance (cited in Parrenas, 361). Both Gloria and Terry spend hard earned money on phone cards which they use to call home every so often, regulating meals, schoolwork, illnesses, financial responsibilities (Parrenas 2001, 371-372),

Emotional strains of transnational mothering include feelings of anxiety, helplessness, loss, guilt, and the burden of loneliness. Mothers negotiate these emotional strains in three central ways: the commodification of love; the repression of emotional strains; and the rationalization of distance, that is, they use regulation communication to ease distance. In general, individual women use all three coping mechanisms, although not always consciously. For the most part, they justify their decision to leave their children behind in the Philippines by highlighting the material gains of the family. And they struggle to maintain a semblance of family life by rationalizing distance. Although a few women explicitly deny the emotional strains imposed by separation on their children, most women admit to the emotional difficulties that they themselves feel. Knowing that they have missed the growing years of children, mothers admit experiencing loss of intimacy in transnational families. In general, a surreal timelessness is felt during the separation that is suddenly catapulted back to reality the moment the family reunites. Confronted with absence of familiarity, transnational 
mothers often feel an insurmountable loss over their prolonged separation from their children.

Many of the domestic workers still grapple with the idea that to give their children a better life, they have to abandon their own to take care of those belonging to others.

The burden of transnational families also puts the onus on the female labourer when the family becomes dysfunctional. When husbands commit infidelity and when children turn to drugs or early marriage, the family and society blame the absent mother. Parrenas' study also point out that many children prefer the presence of their mothers to the material gain her absence brings and that the Filipino family seems to cope better with an absent father than with an absent mother. But because female labourers are more in demand, women have a better chance at providing improvement opportunities for her family.

\section{Cultural Capital and the Filipina Entertainer}

Local cultural contexts likewise inform the creation of the Filipina entertainer. Coming from a culture with a high happiness index despite widespread poverty and which values hospitality and smooth interpersonal relations, the Filipina is conditioned to be a pleasant, attentive host. (Not meaning to essentialise, I use these descriptions as desired traits that are often pursued and praised but not always achieved.) Moreover, a cultural inclination marks the Filipina in comparison to her Southeast Asian sisters and that is her love for performance and her freedom to do it (I use performance here in the entertainment sense). Theatrical and other kinds of performances existed during pre-colonial times but popular Western music and dance was made quotidian with American colonialism in the first half of the 20th century. Performance became even more internalised when it was integrated into the primary, secondary and tertiary curricula as part of Physical Education. Suffice it to say that Filipinos seem take performance seriously, training children to copy song and dance numbers on television the minute they can walk and talk.

Performance has become part of the national psyche so much so that that the karaoke/videoke has become ubiquitous in Filipino homes and social occasions including wakes. Filipino performers are sought after in hotels and bars all over the world. It is a big deal if one wins a singing contest, the public cheers whenever a Filipino wins in the Voice (in its various chapters all over the world), the X Factor, dance contests (the Philippines is a world champion in street dance competitions), even beauty pageants (the reigning Miss Universe is Miss Philippines and this is a very very big deal.) Even boxing champion Manny 
Pacquiao thinks of boxing as performance. Before every fight, he would wish everyone to "enjoy" the pugilistic event, implicit here is his awareness that people paid a lot of money to be entertained.

Performance therefore in whatever form has become cultural capital. Show business has turned poor but talented performers into millionaires. Those less fortunate but equally or somewhat talented become cultural workers. Because of the glamour, and again the material returns, performance like domestic work has become an agency of local desire. When exported to other parts of the world, it joins the ranks of foreign labour subject to the promise and vulnerability of labour migration.

I would like to focus on the female entertainers exported to Japan in the 1980s up to the middle of 2000s. Aside from her talent, the Filipina entertainer is also recruited for her beauty and sex appeal. She undergoes rigorous training in singing and dancing closely monitored by the government lest the recruiter turns into a pimp. But when she arrives in Japan, she is often required to do other forms of entertainment. Now she is called japayuki, i.e. a Japan-bound Filipina or a Filipina entertainer in Japan, a term with negative connotation.

The japayuki is trained to entertain, a geisha without the refinement. Aside from the training in singing and dancing, they are also trained how to highlight their sexuality. Part of the training involved knowing how to deal with Japanese men-how to "steam and present moist towels, pour drinks, sit elegantly, sing karaoke and dance, flatter and flirt with customers" (Faier 2007, 150). According to a study done by Faier (2007), these women would remember details in the lives of these men. They would flatter these men in Japanese, telling them how much they liked them and how they missed them when the men did not visit the bar. In this sense, being "loving" - a practice of affection, caretaking, and careful attention-was a key component of the women's labour in hostess clubs (Faier 2007, 150). According to Anne Allison, for urban Japanese white collar men who are emasculated in their work environment, hostess bars are important sites for rearticulating masculine and class based identities. In these bars, hostesses were paid to make the customers feel special, at ease, indulged or as one customer explained to her, "feel like a man" (cited in Faier 2007, 151). And the Filipina is socially wired to fulfill these functions. The same traits that make her the best caregiver, nurse, nanny allow her to be a good japayuki.

Cultural capital becomes emotional capital in the case of the japayuki. In contrast with the domestic with the domestic worker who becomes a surrogate mother, the japayuki functions as a surrogate wife. The poem Sushi by Banzon (1987) captures the complexity of the japayuki phenomenon. 
Sushi

Also called

Philippine meat.

O Suzy.

I will begin with the last image and work backwards. Referring to the Orientalist image of the Asian woman as courtesan or prostitute, the poem alludes to the Hollywood creation Suzie Wong (The World of Suzie Wong is a novel by Richard Mason whose main characters are Robert Lomax, a young British artist living in Hong Kong, and Suzie Wong, a Chinese prostitute. Its most popular rendition is the 1960 film adaptation directed by Richard Quine). Hollywood's Suzie is mysterious and seductive, a knowledge of secret carnal pleasures implicit in her character. She is every husband's fantasy and every wife's nightmare.

But two previous images contextualise the image of Suzy. She is also called "Philippine meat". The image reminds the reader that Suzy is commodity, an important export necessary to national economic survival. She is pork, beef or worse, carcass transported to earn money for the state. But Suzy does not know this. For her, this subjectivity puts food on her family's table (Faier 2007, 150).

Most of the women came from urban or poor rural communities in the Philippines, often from Manila and its surrounding provinces, few of them had post-secondary education or none were eligible for visas other than entertainer visas. The labor they can provide is "emotional labor", to convince men that they cared for them and were having a good time so that the men would patronize their bars and increase the tabs. Their job as entertainer does not require them to have sex with their customers but some do, thus the stigma was created.

This was worsened when the Marcos government discovered how lucrative sex tourism was. Busloads of Japanese men would come to Manila for rest and recreation. Because of this, Filipino women who go to Japan as entertainers are widely perceived as prostitutes in both countries and disparaged as japayuki or japayukisan.

The image of eating and consumption binds the two images. Suzy's body is meat, Philippine meat, currency to a country's economic survival. But it is also eaten, consumed by a devouring patron whether he is a Japanese customer or the Philippine state. There are many discourses pertaining to food and sex but that will be another paper. Suffice it to say that the consumption of a Filipina body 
provides the transgressive element here. She is metaphorically eaten by the state who acts as her pimp and by the transnational flow of capital and labour.

\section{Failed Desires}

Fulfilled desires make foreign labour appealing despite the challenges. And while many succeeded, there were also those who struggled and failed. The vaginal economy unfortunately makes women migrant workers vulnerable to physical and sexual abuse. According to IBON, 35,000 OFWs are abused annually, a big number of them women. Saudi Arabia is said to be the most dangerous country for OFWs especially female ones. Government lists Singapore, Malaysia, Saipan, the United Arab Emirates, Libya, Kuwait, and the Saudi cities of Riyadh and Jeddah as having the most number of reported cases of abuse (Bleeding Them Dry 1995, 6). OFW centres are full of women who seek protection from abusive employers. The sad news is that they are also vulnerable to abuse even from Philippine embassy personnel. The Philippine local evening news would have horrific stories of maids who jump from their buildings to escape employer brutality of pictures of faces mangled by flat irons.

Some of the notable cases are that of Flor Contemplacion who was hanged in Singapore. Because she became the face of the oppressed female migrant labourer, it caused a rift between Singapore and the Philippines. There is Sara Balabagan, a 14 year old maid in Saudi Arabia who killed her employer to defend herself when he tried to rape her. There is Maricris Joson, killed by the Yakuza when she wanted to return home.

The nameless others are represented by the following texts: The poem Slave Woman of Tarlac, Tarlac by Fatima Lim Wilson (1991) captures the travails of an abused domestic worker.

Slave Woman of Tarlac, Tarlac

(A Filipina Maid Comes Home from Kuwait)

Six months since she's arrived

And yet she does not speak

She must have been chained;

That I guess from the bruises

On her wrists. But she will not

Let me touch them.

She trembles at the sight

Of tall men, more so at those

With shadows on their lips. 
I ply her with green fruits

And with the strains

Of my youth's guitar

But she will not be moved

She wraps her hair

About her like a robe.

Clenches her fists

Forming bullets

With the unseen hand

At night, I long

To draw her to me, to whisper

To her of life's promise:

I will bring back his head

Jutting from the tip

Of his own crescent-shaped sword.

But she pulls away

Withdrawing into the tent

Of her own thoughts

Her eyes flickering, re-living

Her thousand and one

Horrors.

Written from the point of view of a husband, the poem narrates his struggle to restore the normalcy of their lives but the wife continues to live in the horror of her experience. The great hopes the woman carried with her when she left her family and country lie in ruins, cruelly marked by "bruises on her wrists" and her fear of men with "shadows on their lips". Her husband's efforts at comforting her through his youth, his music and possibly even revenge cannot undo her tragedy and she becomes the picture of a life destroyed. The poem suggests that sometimes the social cost of being an OFW far exceeds the material gain it brings.

Some OFWs do not reach home alive. But even in death, they are not spared the bureaucratic neglect of government institutions. Sometimes they die without the respect and honour accorded a new hero. The first chapter of Jose Dalisay's novel (2008), Soledad's Sister, was published first as a short story titled "Woman in a Box". In the story, Dalisay injects humor and irony into the exceptionally tragic as he narrates the activities of a family waiting for the arrival of a cadaver from the Middle East, that of a father executed for a crime he had committed. Because of bureaucratic negligence, the body of a woman arrives instead, that of a 
domestic worker whose death is still a mystery. The family exhibits mixed reactions to the death of their relative-grief, indifference and opportunism. When they decide to go to the mall at the end of the day, one is not sure if this is stoic abandonment or resilience. The OFWs have been seen as the saviour of families and country but their journeys court various kinds of deaths. Upon departure, the OFW dies a little as she is separated from her family. Then her family, bereft of a parent, "dies" of dysfunction. As the story shows, she can actually die at the hands of an abusive employer or be executed for a crime committed, only to die all over again when her body is misplaced by a careless bureaucrat (Banzon and Tope 2012, 547).

I would like to end this study not on a tragic note, the life of an OFW is already tragic as it is, but on a note of hope that has continued OFW sojourns and with the thought that it is possible that some good, other than material gain, has come out of her labour. Leiba Faier's study suggests the possibility of happy endings for the japayukis. Some of them eventually married their customers. The study is set in rural Japan and the context here is that Japanese women are not interested in marrying farmers nor do they want to settle in rural areas. The Filipino women do not mind living in rural Japan, it is still better than what they left behind. And before they are condemned for marrying only for utilitarian purposes, the study finds that they fall in love with their Japanese husbands. Coming from a country that idealises true love and which privileges romantic love and affection, these women again blur the boundaries of service and care. The study cites a 2003 Siemen's Mobile Lifestyle Survey where Filipinos are found to be the most romantic among cellular phone users in six Southeast Asian countries (Faier 2007, 153).

Love is culturally potent, not only in the context of family, but also in creating self-affirmation. In the idealised sense, it is an emotion that should not be transactional. Rightly or wrongly, many of these women feel love is the great leveler and should transcend the barriers of class and race if it is genuine. This "romantic" belief and the Filipina's inclination to express affection openly in contrast to the Japanese woman's restraint, seem to add to her attractiveness as a spouse despite the nature of her profession. For the japayukis, the small kindnesses shown by the Japanese men, their husbands' willingness to help her support the families back home have shifted emotional labour into emotional capital. For Leiba Faier, the women's stories stressed their agency in their marriages. "They act as individual, modern and glamorous subjects who were free to form intimate and romantic relationships regardless of financial, familial and other concerns" (Faier 2007, 153). It is a love allowed in the global stage and the completion of desires that originated from the local trope of family. 
The Japanese government has stopped the importation of Filipina entertainers finding their presence too disruptive to Japanese society. The women who married Japanese men are now being re-trained as caregivers, still unable to escape the subjectivity of maternalism, but this time they have enough social capital to negotiate a better image and social role.

In Singapore, a young film director paid tribute to the Filipina nanny who raised him and his brothers by writing and directing the film Iloilo. Based on the director's childhood experiences with his nanny, the film reminds us that while Filipina maids enter a life of servitude, their surrogate role give comfort to lonely children. A bond is formed between service provider and child clients that can only be described as love. In the film, Terry shields the young boy when his family was falling apart due to the financial crisis. She performs the role the Singaporean mother is too busy to fulfill.

The film is by all means a work of love for and remembrance of someone who invested emotions on her wards. It is the ward's revisit of his childhood now with the comprehension of an adult. It shows the socio-cultural containment that the nanny has to negotiate as a foreign worker, thereby realistically dramatising her strength and vulnerabilities. It is an acknowledgment not only of paid service but of the nanny's sacrifice and care, an affective offering that goes beyond emotional labour. The narrative does not end there. This debut feature film by Anthony Chen is the first Singapore film to win an award at the Cannes Film Festival, the Camera d'Or in 2013. Anthony together with his brothers searched for their nanny and found her in a small farm in Iloilo. The reunion is emotional profit born out of emotional labour.

To conclude, OFW literature and film are on the one hand expressions of displacement or pain but on the other, also expressions of hope. These are testaments of the Filipino woman's courage and resiliency, of love for family and self-sacrifice. They are also chronicles of the cost of the desire for betterment among the world's poor and how their labour is regarded by international capital. In a globalised transnational world, merely the commodified identities of the OFWs are what are seen. Only in literature and film do they become persons. In these texts, local desires become global desires. These texts humanise the process and show its complexity when seen from the point of view of emotional labour and surrogacy. Away from statistics and transnational money, local and global can grow into each other in the most human way. 


\section{References}

Banzon, I. 1987. Sushi. In Paper cage. Manila: The Mabolo Group/Samahang Bagong Buhay Foundation, 22.

Banzon, I. and Tope, L. R. 2012. Travel and diaspora. In An anthology of English writing from Southeast Asia, ed. Patke, R., 545-547. Singapore: Singapore National Library Board.

Bleeding Them Dry. 1995. IBON Facts and Figures, 6.

Chen, A. 2013. Iloilo [DVD]. Directed by Anthony Chen. Paris: Memento Films.

Dalisay, J. 2008. Soledad's sister. Pasig City: Anvil Publishing.

Faier, L. 2007. Filipina migrants in rural Japan and their professions of love. American Ethnologist 34(1): 148-162, https://doi.org/10.1525/ae.2007.34.1.148.

Feminization of Migrant Labor. 1995. IBON Facts and Figures, 8.

Jeyaretnam, P. 1987. Traps. In First loves. Singapore/Kuala Lumpur: Times Books International, 117-132.

Lim, S. C. 2007. Gloria. Asiatic 1(1): 1-15.

Lim, W. F. 1991. Slave woman of Tarlac, Tarlac. In Wandering roots 1978-1988. Pasig City, Philippines: Anvil Publishing, 69.

Pacis, C. 1999. O.C.W. a young boy's search for his mother. Pasig City, Philippine: Anvil Publishing.

Parrenas, R. 2001. Mothering from a distance: Emotions, gender, and intergenerational relations in Filipino transnational families. Feminist Studies 27(2): 361-390, https://doi.org/10.2307/3178765.

Patterns of Migration. 1995. IBON Facts and Figures, 2-4.

Philippine Statistics Authority. 2015. Statistics tables on overseas contract workers $(O C W)$ : 2015. Manila: Philippine Statistics Authority. Retrieved from https://www.psa.gov.ph on 1 October 2016.

. 2012. Total number of OFWs is estimated at 2.2 million (results from the 2011 survey on overseas Filipinos). Reference no. 2012-47. Manila: Philippine Statistics Authority. Retrieved from https://psa.gov.ph/content/total-number-ofwsestimated-22-million-results-2011-survey-overseas-filipinos on 30 May 2015.

Tolentino, R. 2011. Vaginal economy: Cinema and sexuality in Post Marcos, Post Brocka Philippines. Positions 19(2): 229-256, https://doi.org/10.1215/10679847-1331706. . 2009. Globalizing national domesticity: Female work and representation in contemporary women's films. Philippine Studies 57(3): 419-442.

Tope, L. R. 2015. The "new heroes": Literature of the overseas Filipino workers (OFWs). In Literatures in English: New frontiers in research, vol. 24, eds. Zach, W. and Kenneally, M., 437-464. Austria: Stauffenberg Verlag. . 2007. My neighbor, my other: Constructing identities in one's neigborhood. In Writing in Asia: The literatures in Englishes, ed. Thumboo, E., 117-128. Singapore: Ethos Books.

Youngblood, R. 1973. Family strictnesss, social class and political attitudes among Manila high school students. Asian Survey 13(8): 761-771, https://doi.org/ $10.2307 / 2642866$. 